\title{
PELAKSANAAN PENGAWASAN OLEH ATASAN LANGSUNG DI DINAS PERINDUSTRIAN DAN PERDAGANGAN PROVINSI SUMATERA BARAT
}

\author{
Ade Kurnia Kusuma ${ }^{[1]}$, Syahril ${ }^{[2]}$, Ahmad Sabandi $^{[3]}$ \\ e-mail: $\underline{\text { adekurnia.ap.unp@gmail.com }}{ }^{[1]}$, syahril_fip@yahoo.com $^{[2]}, \underline{\text { sabandi @ fip.unp.ac }^{[3]}}$ \\ Universitas Negeri Padang
}

\begin{abstract}
The aim of this study in general is to get a general description of the implementation of supervision by direct superiors at the Department of Industry and Commerse of West Sumatra. While the specific aim of this study is to get an overview of the implementation of supervision by direct supervisors seen from aspects: standard setting, supervision techniques, time of supervision, assessment and follow-up at the Department of Industry and Commerse of West Sumatra. This research is descriptive research. The population of this research is 116 employees of the Department of Industry and Trade of West Sumatra Province. While the sample in this study uses the Slovin formula, which is 56 people. The data collection tool in this study is a questionnaire, which is arranged in the form of a Likert scale that has been tested for validity and reliability. Data is analyzed by using the mean formula. The results of the study show that: the standard setting by direct superiors has illustrated a fairly good supervision with an average score of 2.9; supervision techniques by direct superiors have illustrated fairly good supervision with an average score of 3.3; the time of supervision by direct superiors has described good supervision with an average score of 3.8; the appraisal by direct supervisors at the has described a fairly good supervision with an average score of 3.3; follow-up by direct supervisors has described good supervision with an average score of 3.8. Overall, the implementation of supervision by direct superiors at the Department of Industry and Commerse of West Sumatra has illustrated a fairly good supervision.
\end{abstract}

\section{The Key word: supervision ,direct supervisor, employee}

How to cite : Kusuma, A. K., Syahril, \& Sabandi, A. (2019). Pelaksanaan Pengawasan oleh Atasan Langsung di Dinas Perindustrian dan Perdagangan Provinsi Sumatera Barat. Jurnal Bahana Manajemen, 8(1), 27-34.

This is an open access article distributed under the Creative Commons 4.0 Attribution License, which permits unrestricted use, distribution, and reproduction in any medium, provided the original work is properly cited. @2017 by author and Universitas Negeri Padang.

\section{PENDAHULUAN}

Organisasi merupakan sekumpulan dua orang atau lebih yang memiliki tujuan. Didalam organisasi terdapat pimpinan / atasan langsung dan beberapa pegawai. Pimpinan merupakan orang yang memimpin suatu organisasi. Sedangkan pegawai merupakan pelaksana dalam kegiatan dari perencaaan yang telah ditetapkan bersama dan punya peran yang penting dalam mencapai tujuan organiasi.
Dalam organisasi mempunyai tujuan yang akan dicapai. Untuk mewujudkan tercapainya tujuan maka seorang pimpinan membutuhkan pegawai yang kompeten, karena pegawai merupakan unsur pokok atau unsur terpenting dalam pencapaian keberhasilan organisasi. Menurut (Sabandi, 2013) mengembangkan organisasi yang meningkatkan komitmen dan memberikan arah, kesempatan bertindak atas dasar komitmen. 
Pimpinan atau atasan langsung merupakan orang yang diberi tanggung jawab dalam memimpin suatu organisasi atau instansi. Keberhasilan atasan langsung juga tergantung kepada kerja sama dan komitmen dengan pegawainya agar tercapai dan terlaksana secara efektif dan efisien.

Namun tidak semua pegawai akan menggunakan atau memanfaatkan kompetensi yang ada dalam dirinya atau tidak adanya komitmen untuk mencapai tujuan organisasi, sehingga terjadinya penyimpanganpenyimpangan. Penyimpangan ini terjadi karena terdapatnya beberapa alasan salah satunya adalah karena kurangnya pengawasan yang dilakukan oleh atasan langsung. Untuk menghadapi pegawai yang melakukan penyimpangan ini adalah suatu tantangan bagi pemimpin karena bagaimana upaya pimpinan dapat membuat para pegawai sadar atas tugastugas yang diberikannnya padanya. Salah satu cara pimpinan untuk meminimalisir penyimpangan -penyimpangan yang terjadi didalam organisasi adalah dengan melakukan pengawasan dari pimpinan.

Pengawasan Menurut (Sagala, 2011) adalah fungsi administratif yang setiap administrator memastikan bahwa apa yang dikerjakan sesuai dengan yang dikehendaki. Selanjutnya pengawasan menurut Mocler yang dikutip dalam (Engkoswara \& Komariah, 2011) adalah suatu usaha yang sistematis untuk menetapkan standar pelaksanaan dengan tujuantujuan perencanaan, merancang sistem informasi umpan balik, membandingkan kegiatan nyata dengan standar yang telah ditetapkan sebelumnya, menetukan dan mengukur penyimpangan - peyimpangan, serta mengambil tindak lanjut yang diperlukan untuk menjamin bahwa semua sumber daya perusahaan dipergunakan dengan cara paling efektif dan efisien dalam tujuan-tujuan organisasi.

Berdasarkan pendapat ahli diatas dapat disimpulkan bahwa pengawasan adalah suatu usaha yang dilakukan atasan ke bawahan dengan penetapan standar ,teknik pengawasan ,waktu pengawasan, melakukan penilaian, serta tindak lanjut terhadap kegiatan yang direncanakan agar tercapai tujuan secara efektif dan efisien.

Pengawasan sangat penting dilakukan oleh atasan langsung. Hal ini bertujuan untuk mencegah segala bentuk penyimpanganpenyimpangan yang bisa terjadi selama berlangsungnya proses kerja serta melakukan tindakan perbaikan apabila penyimpangan terjadi. Pelaksanaan pengawasan oleh atasan langsung merupakan upaya untuk menumbuhkan disiplin pegawai yang bersih dan berkompeten demi terwujudnya tujuan pengawasan yang berdaya guna dan berhasil guna, terhadap tugas yang diberikan kepada masing-masing pegawai. 
Pengawasan atasan langsung sangatlah penting dalam suatu organisasi, karena menjadi tolak ukur dalam memberikan penilaian terhadap suatu tugas atau pekerjaan yang dilakukan oleh pegawai baik perorangan atau kelompok. Pengawasan mempunyai peranan penting

Berdasarkan pengamatan penulis selama melaksanakan kegiatan Praktek Lapangan Manajemen Pendidikan (PLMP) di Dinas Perindustrian dan Perdagangan Provinsi Sumatera Barat dari tanggal 20 Juni 2016 sampai dengan 27 Agustus 2016, penulis melihat adanya fenomena-fenomena yang menunjukkan pelaksanaan pengawasan oleh atasan langsung belum terlselenggara dengan baik. Hal ini dapat terlihat dari 1)Pimpinan tidak menegur pegawai yang melanggar peraturan di kantor,karena masih terdapat pegawai yang kehadirannya tidak teratur, sering terlambat dan pulang lebih awal tanpa ada teguran yang berarti sebagai tindakan kepegawaian untuk memperbaiki situasi tersebut. 2)Pimpinan membiarkan pelaksanaan kerja pegawai tidak sesuai dengan aktu yang telah ditetapkan, tanpa adanya pengontrolan yang bertujuan untuk mendisiplinkan pegawai dalam bekerja. Hal ini terlihat masih ada sebagian pegawai yang menunda-nunda pekerjaan. 3)Pimpinan sebagai pengawas hanya menerima informasi secara langsung dari pegawai mengenai pekerjaan tanpa melihat langsung di lapangan. Hal ini terlihat pada saat pegawai yang tidak bekerja ada salah seorang pegawai yang melapor ke pimpinan.

1. Dari fenomena diatas telah menunjukan kurang terlaksananya dengan baik pengawasan oleh pimpinan atau atasan langsung. Jika kondisi ini dibiarkan maka akan berpengaruh terhadap tujuan organisasi yang telah ditetapkandalam mencapai keberhasilan apabila sesuai dengan kriteria yang telah ditentukan.

\section{METODE PENELITIAN}

Jenis penelitian ini adalah penelitian deskriptif. Jumlah populasi penelitian ini adalah 116 orang pegawai, maka besar sampel berdasarkan rumus Slovin adalah 54 orang dari jumlah populasi

Instrumen yang digunakan dalam penelitian berupa angket. Pengumpulan data dilaksanakan dengan mengunjungi Dinas Perindustrian dan Perdagangan Provinsi Sumatera Barat sekolah dan menyebarkan angket ke pegawai yang dijadikan sampel sebanyak 54 orang yang menjadi responden penelitian. Analisis data dilakukan dengan prosedur 1) verifikasi data, 2) klasifikasi dan tabulasi data, 3) pengolahan data dan analisis data.

\section{HASIL PENELITIAN}

Secara umum hasil pengelolaan data mengenai Pelaksanaan Pengawasan oleh Atasan Langsung di Dinas Perindustrian dan 
Perdagangan Provinsi Sumatera Barat dapat dilihat pada tabel 1 .

\section{Tabel 1. Rekapitulasi Pengawasan oleh Atasan Langsung di Disperindag}

\begin{tabular}{|c|c|c|c|}
\hline No. & Rekapitulasi & $\begin{array}{c}\text { Rata- } \\
\text { rata }\end{array}$ & Kategori \\
\hline 1. & Penetapan Standar & 2,9 & Cukup Baik \\
\hline 2. & Teknik Pengawasan & 3,3 & Cukup Baik \\
\hline 3. & Waktu Pengawasan & 3,8 & Baik \\
\hline 4. & Penilaian & 3,3 & Cukup baik \\
\hline 5. & Tindak Lanjut & 3,8 & $\overline{\text { Baik }}$ \\
\hline & Total & $\overline{3,4}$ & Cukup Baik \\
\hline
\end{tabular}

Pada tabel 1 terlihat bahwa skor rata-rata yang paling tinggi mengenai Pelaksanaan Pengawasan oleh Atasan Langsung di Dinas Perindustrian dan Perdagangan Provinsi Sumatera Barat terdapat pada indikator waktu pengawasan dan tindak lanjut dengan skor ratarata 3,8 dan skor yang paling rendah pada pada indikator penetepan standar dengan skor ratarata 2,9 .

Secara keseluruhan skor rata-rata mengenai Pelaksanaan Pengawasan oleh Atasan Langsung di Dinas Perindustrian dan Perdagangan Provinsi Sumatera Barat adalah 3,4. Skor ini berada pada kategori cukup baik, ini berarti Pelaksanaan Pengawasan oleh Atasan Langsung di Dinas Perindustrian dan Perdagangan Provinsi Sumatera Barat sudah terlaksana dengan cukup baik.

\section{PEMBAHASAN}

Pada bagian ini akan dikemukan hasil penelitian Pelaksanaan Pengawasan oleh Atasan
Langsung di Dinas Perindustrian dan Perdagangan Provinsi Sumatera Barat pada indikator: penetapan standar, teknik pengawasan, waktu pengawasan, penilaian dan tindak lanjut.

Dari hasil penelitian Pelaksanaan Pengawasan oleh Atasan Langsung di Dinas Perindustrian dan Perdagangan Provinsi Sumatera Barat berdasarkan aspek penetapan standar, skor yang tertinggi pada sub indikator sasaran dengan skor 3,1 yaitu pada kategori cukup baik. Kategori terendah diperoleh sub indikator tujuan dengan capaian skor 2,8 dengan kategori cukup baik. Secara keseluruhan pelaksanaan pengawasan oleh Atasan Langsung di Dinas Perindustrian dan Perdagangan Provinsi Sumatera Barat dilihat dari aspek penetapan standar adalah 2,9 yang ada pada kategori cukup baik. Hal ini mungkin disebabkan karena masih belum sepenuhnya atasan langsung menetapkan standar secara maksimal, sehingga karyawan masih merabaraba kemana kegiatan tersebut harus diarahkan.

Dari hasil penelitian pelaksanan pengawasan oleh Atasan Langsung di Dinas Perindustrian dan Perdagangan Provinsi Sumatera Barat melalui teknik pengawasan telah berjalan cukup baik dengan skor rata-rata 3,3. Hal ini ditunjukkan dengan skor rata-rata tertinggi di peroleh oleh aspek melalui laporan baik lisan maupun tertulis dengan nilai 3,9, sedangkan untuk skor rata-rata terendah 
diperoleh oleh aspek pengamatan langsung atau observasi dengan nilai 2,9. . Hal ini mungkin disebabkan karena belum terlaksana dengan baik teknik pengawasan yang dilakukan oleh Atasan Langsung. Sebaiknya Atasan Langsung tersebut terus meningkatkan pelaksanaan pengawasan melalui teknik pengawasan agar pelaksanaan pekerjaan pegawai akan lebih optimal.

Dari hasil penelitian pelaksanan pengawasan oleh Atasan Langsung di Dinas Perindustrian dan Perdagangan Provinsi Sumatera Barat melalui waktu pengawasan telah berjalan baik dengan skor rata-rata 3,8. Hal ini ditunjukkan dengan skor rata-rata tertinggi di peroleh oleh pengawasan preventif dan pengawasan progresif dengan nilai 3,9, sedangkan untuk skor rata-rata terendah diperoleh oleh pengawasan represif dengan nilai 3,8 .

Hal ini menunjukkan bahwa aspek waktu pengawasan dalam pelaksanaan pengawasan oleh Atasan Langsung di Dinas Perindustrian dan Perdagangan Provinsi Sumatera Barat baik dan perlu adanya peningkatan lagi dimasa akan datang.

Dari hasil penelitian pelaksanan pengawasan oleh Atasan Langsung di Dinas Perindustrian dan Perdagangan Provinsi Sumatera Barat melalui penilaian telah berjalan dengan cukup baik dengan skor rata-rata 3,3. Hal ini ditunjukkan dengan skor rata-rata tertinggi di peroleh oleh penilaian formatif dengan nilai 3,5, sedangkan untuk skor rata-rata terendah diperoleh oleh penilaian sumatif dengan nilai 2,9. Hal ini mungkin disebabkan karena Atasan Langsung belum maksimal dalam penilaian terhadap pelaksanaan tugas yang dilakukan pegawai, sehingga pegawai kurang mengetahui hasil dari pekerjaan yang telah dibuat apakah sesuai dengan prosedur kerja atau belum. Sebaiknya Atasan Langsung perlu meningkatkan lagi pelaksanaan pengawasan dalam hal penilaian, Atasan Langsung hendaknya menilai hasil pekerjaan pegawai dari laporan tertulis yang disusun pegawai dan langsung mengunjungi pegawai untuk menanyakan hasil pekerjaannya atau pegawai dipanggil untuk memberikan laporan lisan

Dari hasil penilaian pelaksanan pengawasan oleh Atasan Langsung di Dinas Perindustrian dan Perdagangan Provinsi Sumatera Barat melalui tindak lanjut telah berjalan baik dengan skor rata-rata 3,8. Hal ini ditunjukkan dengan skor rata-rata tertinggi di peroleh oleh penyampaian pujian dan penghargaan dengan nilai 3,9, sedangkan untuk skor rata-rata terendah diperoleh oleh pemberian kegiatan pembinaan dan bimbingan dan pemberian peringatan, sanksi dan hukuman dengan nilai 3,8 Hal ini menunjukkan bahwa aspek tindak lanjut dalam pelaksanaan pengawasan oleh Atasan Langsung di Dinas Perindustrian dan Perdagangan Provinsi 
Sumatera Barat baik dan perlu adanya peningkatan lagi dimasa akan datang.

Berdasarkan hasil penelitian dengan menggunakan instrument penelitian yang berupa angket, maka dilihat bahwa secara keseluruhan tentang Pelaksanaan pengawasan oleh Atasan Langsung di Dinas Perindustrian dan Perdagangan Provinsi Sumatera Barat dapat di kategorikan sudah menggambarkan pelaksanaan pengawasan yang cukup baik. Hal ini dapat dilihat dari skor rata-rata yang diperoleh sebesar $(3,4)$. Skor tertinggi adalah pada indikator waktu pengawasan dan tindak lanjut dengan skor ratarata 3,8 dengan kategori baik, sedangkan skor terendah pada pada indikator penetapan standar dengan skor rata-rata 2,9 dengan kategori cukup baik.

\section{KESIMPULAN DAN SARAN}

Berdasarkan hasil penelitian mengenai Pelaksanaan Pengawasan oleh Atasan Langsung di Dinas Perindustrian dan Perdagangan Provinsi Sumatera Barat maka dapat diambil kesimpulan sebagai berikut :

1. Secara umum Pelaksanaan pengawasan oleh Atasan Langsung di Dinas Perindustrian dan Perdagangan Provinsi Sumatera Barat dapat di kategorikan sudah menggambarkan pelaksanaan pengawasan yang cukup baik. Hal ini dapat dilihat dari skor rata-rata yang diperoleh sebesar $(3,4)$.

2. Pelaksanaan pengawasan oleh Atasan Langsung di Dinas Perindustrian dan
Perdagangan Provinsi Sumatera Barat dapat di lihat dari aspek penetapan standar telah dilaksanakan dengan cukup baik. Hal ini dapat dilihat dari skor rata-rata yang diperoleh sebesar $(2,9)$.

3. Pelaksanaan pengawasan oleh Atasan Langsung di Dinas Perindustrian dan Perdagangan Provinsi Sumatera Barat dapat di lihat dari aspek teknik pengawasan telah dilaksanakan dengan cukup baik. Hal ini dapat dilihat dari skor rata-rata yang diperoleh sebesar $(3,3)$.

4. Pelaksanaan pengawasan oleh Atasan Langsung di Dinas Perindustrian dan Perdagangan Provinsi Sumatera Baratdapat di lihat dari aspek waktu pengawasan telah dilaksanakan dengan baik. Hal ini dapat dilihat dari skor rata-rata yang diperoleh sebesar $(3,8)$.

5. Pelaksanaan pengawasan oleh Atasan Langsung di Dinas Perindustrian dan Perdagangan Provinsi Sumatera Barat dapat di lihat dari aspek penilaian telah dilaksanakan dengan cukup baik. Hal ini dapat dilihat dari skor rata-rata yang diperoleh sebesar $(3,3)$.

6. Pelaksanaan pengawasan oleh Atasan Langsung di Dinas Perindustrian dan Perdagangan Provinsi Sumatera Baratdapat di lihat dari aspek tindak lanjut telah dilaksanakan dengan baik. Hal ini dapat 
dilihat dari skor rata-rata yang diperoleh sebesar $(3,8)$.

Berdasarkan pembahasan dan hasil penelitian diatas, adapun sasan dari penulis berupa:

1 Atasan Langsung lebih meningkatkan lagi pelaksanan pengawasan dalam menetapkan standar dengan maksimal dengan menguji cobakan terlebih dahulu standar yang ditetapkan sebelum menilai hasil pekerjaan pegawai Dinas Perindustrian dan Perdagangan Provinsi Sumatera Barat, sehingga pegawai lebih terarah dalam melaksanakan tugas.

2 Atasan Langsung lebih meningkatkan lagi pelaksanaan pengawasan memalui teknik pengawasan agar pegawai di Dinas Perindustrian dan Perdagangan Provinsi Sumatera Barat diharapkan menjadi lebih disiplin dan mematuhi peraturan yang telah ditetapkan, serta teliti dalam melakukan perkerjaan. Sebaiknya pengawasan melalui teknik pengawasan ini lebih dipertahankan lagi serta ditingkatkan untuk kedepannya.

3 Atasan Langsung lebih meningkatkan lagi pelaksanaan pengawasan memalui waktu pengawasan agar pegawai di Dinas Perindustrian dan Perdagangan Provinsi Sumatera Barat diharapkan melaksanakan pekerjaan sesuai dengan waktu yang telah ditetapkan, apabila terdapat kesalahan, Atasan Langsung akan memberikan petunjuk cara kerja yang benar kepada pegawai. Sebaiknya pengawasan melalui waktu pengawasan ini dipertahankan lagi serta ditingkatkan lagi kedepannya.

4 Atasan Langsung lebih meningkatkan lagi pelaksanaan pengawasan melalui penilaian, baik penilaian formatif maupun sumatif dengan membandingkan hasil pekerjaan pegawai dengan standar yang telah ditetapkan. Sebaiknya pengawasan melalui penilaian ini dipertahankan lagi serta ditingkatkan lagi kedepannya.

5 Atasan Langsung lebih meningkatkan lagi pelaksanaan pengawasan melalui tindak lanjut terhadap pegawai yang mengalami hambatan dan penyimpangan dalam melaksanakan tugas. Jika pegawai melakukan pelanggaran dalam pelaksanaan tugas, atasan langsung sebaiknya memberikan sanksi sesuai dengan peraturan yang telah ditetapkan. Sedangkan pegawai yang memberikan loyalitas kerja, hendaknya diberikan reward dan kenaikan pangkat.

6 Pegawai Dinas Perindustrian dan Perdagangan Provinsi Sumatera Barat agar lebih memperhatikan Atasan Langsung dalam melakukan pengawasan, sehingga Atasan Langsung akan lebih mudah dalam melakukan pengawasan.

\section{DAFTAR PUSTAKA}

Engkoswara, \& Komariah, A. (2011). 
Administrasi Pendidikan. Bandung:

Alfabeta.

Sabandi, A. (2013). Supervisi Pendidikan Untuk

Pengembangan Profesionalitas Guru

Berkelanjutan. Jurnal Ilmiah Ilmu

Pendidikan, 13(2), 1-9.

Sagala, syaiful. (2011). Manajemen Strategik dalam Penigkatan Mutu Pendidikan. (Alfabeta, Ed.). Bandung. 